\title{
MED TO TUNGER
}

Skabelsesberetninger og ritualiseret praksis omkring et innovationsprojekt

NANA VAABEN

„Kaffe?“ spurgte Peter, som var leder af den kommunale innovationsafdeling. Han rakte mig et smukt udsmykket porcelænskrus uden hank med abstrakt sorthvidt mønster - et af den slags krus, man kan holde om med begge hænder. Vi sad på høje barstole med græsgrønne polstrede sæder omkring et tilsvarende højt bord. En flad oval lampe kastede gennem de lilla lameller i skærmen et behageligt lys ned over porcelæn, stempelkander og papirer. Vi var omgivet af store vinduespartier, hæve-sænke-borde med computere og fleksible vægge, der gjorde det muligt, at rummene kunne skifte størrelse og form efter behov. Alt var nyt. Når man kiggede ud ad vinduet, var der udsigt til en blomstrende have, hvor der var opsat forskellige træningsredskaber af solidt træ. På den modsatte side var der udsigt til en korridor af glas og videre gennem korridoren til en parkeringsplads fyldt med biler og cykler. En gang imellem passerede kittelklædte plejemedarbejdere eller gamle mennesker med rollator eller elektrisk kørestol igennem glaskorridoren. De var på vej til eller fra et af de mange små hjem i det høje etagebyggeri, der udgjorde størstedelen af det plejehjem, vi befandt os i, og hvis indretning og æstetiske udtryk på alle tænkelige måder adskilte sig fra de lyse, fleksible omgivelser, hvor Peter og jeg sad og drak kaffe.

Rummene var blevet specielt designet til at huse en ,platform for innovation inden for ældrepleje“, forklarede Peter. Normalt sad han i kommunens kontorbygning et andet sted $\mathrm{i}$ byen, men $\mathrm{i}$ dag havde han inviteret mig herhen for at tale om mit kommende feltarbejde. Han forklarede blandt andet og med henvisning til de nye, ,innovationsvenlige“ omgivelser, hvordan han et par år forinden havde måttet genforhandle nogle af kommunens økonomiske prioriteringer for at få lokalerne indrettet. Oprindeligt var kommunalpolitikerne i forbindelse med nogle budgetforhandlinger nået frem til at afsætte penge til etableringen af et „forskningsplejehjem“, men efterfølgende havde det vist sig, at forskning var 
ualmindeligt dyrt. „Og hvad skulle vi stille op med et forskningsplejehjem, hvis vi ikke havde råd til noget forskning at putte i det?" spurgte han retorisk.

Det, vi så gjorde, det var, at vi sagde: 'Vi vil gerne konvertere de her penge til en modernisering af udestuen på plejehjemmet.' Bygningen var der i forvejen. Det var et meget kedeligt lokale - det var mørkt og blev brugt til ledermøder og sådan noget $-\mathrm{ja}$, i og for sig til noget af det, som det også bliver brugt til i dag, men det var bare et rigtig kedeligt lokale. Så fik vi det i stedet moderniseret, og vi fik en engangsdriftsbevilling, som handlede om at få opgaverne i gang. Og så kan man sige, hvad er det så, vi skal lave her? Og der gjaldt det jo om at tage de projekter, der havde elementer af forskning i sig, og sige, at nu er de en del af det, der kører her. For vi var jo i gang med en masse ting, der kunne danne en grundstamme [...] Og på det tidspunkt begyndte der jo også at komme rigtig mange finansieringskilder ind til det her felt. Det begynder at blive et fokusfelt, innovation, ikke. Og det bliver det ord, man skal bruge, ikke.

For at understøtte en ,platform for innovation“ som erstatning for det ellers vedtagne forskningsplejehjem var der i kommunen blevet etableret en innovationsafdeling, og den var Peter blevet leder for. Foruden ham selv bestod afdelingen af en projektleder, som i mellemtiden var holdt op og var blevet erstattet af en anden, som nu var ved at overdrage arbejdet til en tredje projektleder. Derudover var der tilknyttet et par studentermedhjælpere og medarbejdere, hvis ansættelser afhang af, om der kunne skaffes fondsmidler.

Det innovationsprojekt, vi skulle snakke om, mens vi drak kaffe, var det største af de igangværende projekter, som skulle „danne grundstamme“, og det skulle huses i de nyindrettede lokaler, vi sad i. Projektet handlede om at forbedre ældre menneskers livskvalitet gennem samskabelse (,co-creation“), innovation og samarbejde mellem plejehjem og private virksomheder. Eller rettere, og som jeg senere skulle finde ud af, fortalte nogle af de involverede personer undertiden, at projektet handlede om at forbedre ældres livskvalitet, mens det andre gange (af og til af de samme mennesker) blev omtalt som et papirprojekt, der ikke havde noget som helst at gøre med virkeligheden, eller som et projekt, der skulle skabe vækst og nye markeder for private virksomheder. Det er netop sameksistensen af disse vidt forskellige fortællinger om ét og samme projekt, jeg vil sætte fokus på i denne artikel.

At se på fortællinger i studier af organisationer og forandringsprocesser er en udbredt tilgang, men da fortællingerne i denne felt jo handlede om innovation og dermed om „skabelse“ af noget nyt, vil jeg ikke bare betragte dem som fortællinger, men mere specifikt som en form for skabelsesberetninger. Jeg vil vise, hvordan bestemte magtfulde og formaliserede skabelsesberetninger i form af forskellige projektbeskrivelser på den ene side opretholdes, isoleres og ind- 
rammes gennem ritualiseret praksis, men også hvordan den selvsamme indramning gør aktører i stand til at udøve modmagt og distancere sig fra fortællingerne ved at gøre dem til en slags ,,spil“, der ikke har noget med virkeligheden at gøre. Og endelig vil jeg komme ind på, hvordan de forskellige fortællinger alligevel indvirker på hinanden, griber ind praksis og skaber vanskelige moralske dilemmaer og „doublebinds“ for nogle af de involverede personer.

\section{Historierne om innovationsprocessen}

Når jeg undervejs talte med nogle af de flere hundrede ledere, medarbejdere, beboere og eksterne samarbejdspartnere fra virksomheder og andre organisationer, der deltog i projektet, fik jeg vidt forskellige beretninger om, hvordan det var forløbet, hvad der havde ledt til hvad, og hvilket formål det hele tjente. Fortællingerne kom til udtryk i de mange officielle beretninger i form af skriftlige og visuelle præsentationer på møder, i rapporter, projektbeskrivelser, pjecer og hjemmesidetekster. Men jeg lyttede også til mange mundtlige fortællinger.

De ældre mennesker, hvis livskvalitet projektet (ifølge nogle) drejede sig om, havde ikke det store at fortælle. De fleste af dem led af demens, og hvis de havde været involveret i projektet, havde de ingen erindring om det. Plejepersonalet var meget splittet. Nogle syntes, innovation var spændende og nødvendig, og havde haft gode oplevelser med projektet. Andre var slet ikke klar over, at de indgik i et innovationsprojekt eller i så fald hvilket, og endnu andre var decideret imod projektet og mente, at den slags skrivebordskonstruktioner kom der alligevel ikke noget ud af. Blandt de sidstnævnte var Bjørn, som modvilligt havde stillet op til interview sammen med en kollega, fordi deres leder havde bedt dem om det. „Det er i øvrigt fjerde gang, vi bliver evalueret, “ konstaterede han, mens han satte sig til rette i stolen og indstillede sig på at bruge den næste time af sin i forvejen travle dag på at snakke med mig. Han var bekymret for, at innovationsprojektet (ligesom evalueringer og interviews) ville trække hans tid og opmærksomhed væk fra de gamle. „Der er jo kun den samme spand vand,“ forklarede han. „Hvor kommer tiden til det alt sammen fra? Fra beboerne!" Mange af de ansatte var bekymrede på lignende vis. „Store, dyre projekter“, som de tvivlede på, der kom noget ud af. „Kunne de penge ikke have været brugt lidt mere fornuftigt?" Hen imod slutningen af interviewet sukkede Bjørn tungt og kiggede ned i bordet: „Nogle gange, når jeg går forbi og kigger ind i glaskontoret dernede [de nyistandsatte lokaler], så tænker jeg, at det er, som om de der projektmennesker lever i en helt anden virkelighed end den, jeg kender til.“

På den måde kunne man blandt plejepersonalet støde på en ret skeptisk fortælling om innovationsprojektet. Men det var ikke så enkelt, at plejepersonalet 
var imod, og de såkaldte „projektmennesker“ var for. En del af plejepersonalet syntes, det var spændende at være med i et innovationsprojekt, mens ganske mange af projektets centrale ledere og projektledere var fuldstændig enige med skeptikerne og delte deres bekymring for, at projektet af bureaukratiske eller politiske grunde skulle ende som en dyr papirøvelse.

Der var med andre ord flere og meget forskellige fortællinger om ét og samme projekt, og i det følgende vil jeg se nærmere på, hvordan disse meget forskellige fortællinger sameksisterede og indvirkede på hinanden, og på, hvordan de forskellige aktører forsøgte at navigere imellem dem.

\section{Narrativ organisationsforståelse}

Inden for organisationsforskningen har en narrativ tilgang ifølge organisationsforskeren Anne Reff Pedersen (2014) siden midten af 1900-tallet været anset for en gængs metode, hvor inspirationen især blev hentet i litteraturforskningen og strukturalismen. Her har forskerne blandt andet koncentreret sig om at identificere forskellige mytearketyper, som kunne genkendes i ansattes forandringsfortællinger, der kunne antage form af forskellige ,plots“ som for eksempel et togt, et fald, en krig eller et svindelnummer. Som Pedersen forklarer, er det interessante dog ikke alene, at man kan identificere arketyper eller plots og dermed klassificere, hvilken slags forandringsfortælling der er tale om. De forskellige plots tilbyder også forskellige begivenheder og roller, som man kan fortælle sig selv ind i, hvis man for eksempel forsøger at skabe mening i et innovationsprojekt på sin arbejdsplads. Dermed åbner hun for en mere processuel og aktørorienteret tilgang og henviser til, hvordan interessen for narrativ organisationsforskning i stigende grad har flyttet sig fra en strukturalistisk søgen efter ,store“ eller universelle fortællinger, klassificeringer og arketyper til i stedet at undersøge små lokale fortællinger og måderne, de bliver til på gennem menneskers interaktion med hinanden og forsøg på at skabe mening (Pedersen \& Johansen 2011; Pedersen 2014:308-14). En sådan interesse for meningsskabende processer og „små fortællinger“ inden for organisationsforskningen ses eksempelvis i den stigende interesse for ,,antenarrativer" (Boje 2006), der er små fragmenterede og ufærdige fortællinger, der dårligt nok er formet, men som hele tiden er under tilblivelse og i bevægelse, og som kobler sig til hinanden på kryds og tværs i netværk og processer, der handler om ,sensemaking“ (ibid.; Humle 2014).

Også inden for antropologien ses en bevægelse fra et fokus på at kategorisere og opdele historier og myter i forskellige genrer og typer til et fokus, der er mere processuelt og „,mikroskopisk“. Den første tilgang forbindes inden for antropologien især med Claude Lévi-Strauss, der har lavet adskillige strukturali- 
stiske myteanalyser. Siden er antropologer begyndt at interessere sig for de små fortællinger, der måske mere kommer til udtryk som brudstykker af samtaler mellem fortællere og medfortællere (Ochs \& Capps 2001), og som ofte handler om at skabe mening eller forstå sig selv og sin rolle i forhold til de fællesskaber, man indgår i eller ekskluderes fra (Jackson 2002, 1998).

På den baggrund var det forventeligt, at der fandtes mange forskellige fortællinger om det omtalte innovationsprojekt, at de blev fortalt på kryds og tværs, og at de formede ,plottet“ på forskellige måder. Men det var også tydeligt, at der i visse sammenhænge var bestemte forventninger til, hvordan historien om projektet skulle udlægges, hvilke ord der skulle indgå, og hvilken form den skulle have. I resten af artiklen vil jeg se på, hvordan disse forventninger kom til udtryk, og hvordan nogle af historierne formede en slags moderne skabelsesberetning, der fremstillede innovationsprocessen som et menneskeskabt og styrbart værk. Samtidig cirkulerede myriader af andre historier og versioner rundtomkring på de ansattes computere og i mundtlige overleveringer. De koblede begivenhederne sammen på andre måder, lagde vægt på noget, som var usynligt i de „officielle beretninger", og udgjorde samtidig en mulighed for at udøve modmagt.

\section{Historier om styring af innovation}

Projektet gav anledning til store mængder skriftlige og visuelle fremstillinger af, hvordan det var forløbet eller ville forløbe, og hvad der var kommet ud af det eller ville komme ud af det. Der blev produceret projektbeskrivelser, PowerPointpræsentationer, statusrapporter, hjemmesidetekster, informationsmateriale, invitationer, fondsansøgninger, samarbejdskontrakter, evalueringer og meget andet.

Allerede i takt med at ideen til projektet udviklede sig, opstod der strategiske overvejelser om, hvordan projektet skulle beskrives for at opnå fondsmidler til at gennemføre det. De personer, der skrev ansøgningen til den relevante fond, en projektleder fra kommunen og en konsulent fra en privat virksomhed, var bevidste om, at de dels skulle leve op til bestemte kriterier og dels skulle overbevise styrelsen bag fonden om, at projektet var styrbart og kunne „sikre“, at det førte til det ønskede resultat: innovation.

Det var imidlertid ikke alle de opstillede kriterier, de syntes gav mening. Et af kriterierne for at opnå fondsmidler var, at der indgik nogle ,partnervirksomheder“. Men eftersom tanken var, at hele projektet skulle funderes på en indledende etnologisk undersøgelse af, hvad ældre mennesker overhovedet fandt vigtigt for deres livskvalitet, kunne man af gode grunde endnu ikke vide, hvilke virksomheder det ville være relevant for kommunen at samarbejde med. Projektlederen, der var med til at forfatte ansøgningen, forklarede: 
Vi ville jo gerne holde fast i, at vi reelt gerne ville høre, hvad de ældre ønskede, og først derefter kunne vi koble virksomheder på. Altså helt ærlig brugerdreven innovation. Vi kunne jo ikke først komme med en masse virksomheder og så få det til at passe. Men styrelsen ville jo have, at vi skulle have nogle samarbejdspartnere for overhovedet at give penge. Og så tænkte vi, at vi jo godt kunne have sådan nogle generelle, overordnede samarbejdspartnere (i Vaaben 2013:44).

For at leve op til styrelsens kriterier ringede projektlederen derfor rundt til en række store virksomheder og spurgte, om de ville være ,generelle, overordnede samarbejdspartnere". De skulle ikke investere i noget, men være behjælpelige med kontakter, råd og vejledning senere i processen. Det ville de alle sammen gerne være med til. På den måde resulterede kriterierne $i$, at der blev formuleret en projektbeskrivelse efter en lineær projektmodel, der kunne overbevise styrelsen om, at der var styr på processen, og at man kunne „sikre“, at netop de aktører og aktiviteter, som fonden gerne ville støtte, var involveret på en måde, der kunne føre til innovation og værdiskabelse.

Antropologen Simon Lex, der også har studeret innovationsprocesser, har vist, hvordan noget tilsvarende skete i forbindelse med, at postvæsenet ville satse på innovation og opfindelse af nye forretningsområder, nu hvor folk efterhånden var holdt op med at sende hinanden breve. Også her blev ambitionerne om at skabe innovation omsat til en lineær projektmodel, der præsenterede en styrbar og rationel proces med milepæle og kæder af aktiviteter, som ville føre til en spurt frem mod et prædefineret udkomme i fremtiden. Men som han også beskriver, var netop denne projektmodel samtidig med til at spænde ben for den innovationsproces, som alle aktørerne var så ivrige for at få til at finde sted (Lex 2016).

I plejehjemsprojektet opstod der lignende problemer, og da jeg interviewede en økonom i styrelsen bag fonden, som endte med at støtte projektet, understregede hun ganske som forventet, at de havde en række standardkriterier at gå ud fra, når de skulle udvælge støtteværdige projekter. De skulle involvere brugerinddragelse og samarbejde - gerne mellem offentlige og private virksomheder og samtidig, forklarede hun, skulle de „have nogle perspektiver i sig“ og føre til „noget vækst og beskæftigelse på sigt“. Men hun forklarede mig også, at der var en lang række regler for statsstøtte, som blandt andet skulle forhindre konkurrenceforvridning, men som samtidig besværliggjorde netop den slags samarbejdsog innovationsprojekter, som fonden gerne ville støtte. For at understrege sin pointe printede hun en tyk stak papirer med paragraffer og EU-lovgivning, som hun gav mig med. Paragrafferne forstod jeg ikke meget af, men det var tydeligt, at økonomen havde et budskab. Hun kunne godt forstå de vanskeligheder, projektlederne oplevede, men hun havde nogle rammer, hun skulle agere inden for. Det viste sig i øvrigt, at medarbejderne i styrelsen også godt kunne forstå, at det 
var smartere at vente med at udvælge ,partnervirksomheder“, til man havde fundet ud af, hvad det egentlig var, de ældre ønskede sig. Derfor fandt de en løsning med at opdele bevillingerne i forskellige faser, hvorefter de generelle overordnede partnere, som projektlederen havde ringet til, gled ud i periferien og ikke kom til at spille nogen nævneværdig rolle.

På den måde var det tydeligt, at selv om der var formelle kriterier, som bevirkede, at projektet måtte beskrives som en lineær proces, hvor afviklingen af bestemte aktiviteter og involvering af bestemte aktører blev beskrevet som netop det, der førte til eller ,sikrede“ et innovativt og værdiskabende resultat, foregik der parallelt hermed en anden kommunikation mellem styrelse og ansøger. Styrelsen bag fonden viste sig at være til at tale med. De havde ligefrem stor forståelse for, at visse af de formelle kriterier havde uheldige virkninger og måtte bøjes.

\section{Historier om læring og måling af innovation}

Ud over at fondens kriterier og formkrav førte til en projektbeskrivelse, der præsenterede projektet som en lineær, styrbar og planlæggelig vej mod skabelse af innovation og værdi i fremtiden, havde styrelsen bag fonden også et ønske om at kunne lære af de støttede projekter og måle på, ,hvad der virkede bedst" $i$ innovationsprocesser generelt. Således kunne man på styrelsens hjemmeside læse følgende:

Bestyrelsen forventer sig meget af disse projekter. [] i 2008 vil vi i bestyrelsen også lægge stor vægt på, at der gennemføres effektmålinger af de projekter, der afsluttes. Det er centralt, at vi får målt på effekter af alle projekter, så vi får fornyet viden om, hvilke metoder der virker bedst (i Vaaben 2013:68).

Sådanne forventninger om at lære ved at måle på effekter kom også til at præge måden, hvorpå historierne om projektet formede sig. Derfor var der på kommunens initiativ forud for projektets igangsættelse blevet gennemført en såkaldt „nulpunktsmåling“ af plejehjemsbeboernes livskvalitet. Målingen blev foretaget af et konsulenthus, som kommunen havde en aftale med, og tanken var, at man senere kunne lave en „eftermåling“ og sammenligne de to målinger for at afgøre effekten af projektet. Ingen kunne imidlertid huske ret meget om denne „nulpunktsmåling“.

En af grundene var, at projektet varede fire år. Den gennemsnitlige levetid for beboerne på det aktuelle plejehjem var også fire år, så statistisk set ville halvdelen af beboerne være døde, når projektet sluttede, og nye ville være flyttet ind $\mathrm{i}$ deres boliger. Dem, man ville komme til at måle på ved en eventuel eftermåling, ville derfor være nogle helt andre mennesker end dem, man havde involveret $\mathrm{i}$ 
„nulpunktsmålingen“ og i projektet. Desuden var målingen slet ikke tilpasset ældre mennesker og tog for eksempel ikke højde for, at livskvaliteten hos mennesker sent $\mathrm{i}$ livet nok ikke holder sig på et konstant niveau gennem fire år, så hvad skulle man egentlig holde en eftermåling op imod? Af disse og mange andre grunde virkede en før- og eftermåling af beboernes livskvalitet ikke meningsfuld for projektlederne, hvorfor de havde glemt alt om „nulpunktsmålingen“. Men det betød ikke, at de havde glemt, at de skulle redegøre for de kausale „effekter“ af projektets forskellige aktiviteter. Derfor brugte projektlederne meget tid på at diskutere, om delprojekterne kunne siges at have ført til noget, man kunne definere som innovation, og i så fald om man med rette kunne sige, at denne innovation var en kausal effekt af et bestemt delprojekt.

Én af disse diskussioner fandt sted, mens jeg interviewede to af projektlederne sammen. I det lille stykke interviewudskrift nedenfor diskuterer de et delprojekt, der handlede om at afprøve engangsvarmepuder fra et lille nyoprettet firma, der havde udviklet puderne til hospitalsbrug og nu gerne ville undersøge, om de også kunne bruges inden for plejesektoren. Netop dette delprojekt havde projektlederne diskuteret mange gange, blandt andet fordi det involverede produkt, varmepuderne, ikke var blevet udviklet undervejs, og derfor havde de vanskeligt ved at få øje på det innovative resultat af processen - og dog:

Pernille: Altså, jeg vil sige, at det havde været innovation, hvis han [virksomhedens ejer] havde udviklet sit produkt [...], så jeg synes ikke, det er en produktinnovation. Jeg synes, det er en konceptinnovation i forhold til, at han får involveret medarbejderne og simpelthen får udfordret deres tankesæt og deres måde at arbejde med deres beboere på.

Paula: Det er i virkeligheden det, jeg synes, har den største rækkevidde, men altså, det er jo helt utiltænkt. Fuldstændig. For det er jo ligegyldigt, hvilket produkt han havde haft, hvis han har kunnet sige: 'Skal vi ikke lige tage den enkelte beboer og sige: Prøv lige at forholde dig til, hvad han kunne have glæde af.'

Pernille: Så kan man også sige, at det er også en markedsinnovation, og det er nok det, som for mange af virksomhederne har været den største motivationsfaktor. Det her med at finde ud af, hvordan de kunne komme ind på det her marked.

Paula: Det er jeg helt enig i. Det er jo derfor, de [virksomhederne] overhovedet har meldt sig.

Pernille: Projektambitionen i starten har været, at der skulle udvikles på produktområdet, fordi det meget har været det, der har været italesat fra projektets side [...] Men med de øjne, vi sidder med nu i projektet, ja, så giver det selvfølgelig rigtig god mening, og ja, det er da det, der er ideen med projektet. Det er, at virksomheden kan se et marked inde hos kommunen. Det er jo først og fremmest derfor, vi har det her samarbejde, men kommunen vil gerne have livskvalitet ud af det, og virksomheden vil gerne have kroner og ører ud af det (i Vaaben 2013:116). 
I dette lille stykke samtale bruger de to projektledere nogenlunde de samme kriterier for innovation, som man kan finde ved at konsultere teoretiske definitioner på innovation. Sådanne definitioner er ofte inddelt i flere led, hvoraf et af dem handler om, at der skal være tale om en idé, der er ny, og som bryder med noget eksisterende. Et andet led handler om, at den skal være implementeret, solgt, omsat til handling, virkeliggjort eller på anden måde gennemført, så det har ført til et resultat eller et produkt, og et tredje led kan handle om processen og om, at den for eksempel skal være intenderet og ikke tilfældig eller ustyrlig (Ven et al. 2008:9; Osborne \& Brown 2005:121-23; Sørensen \& Torfing 2011:29).

Som det ses i interviewudklippet, prøver de to projektledere sig frem og overvejer, hvilket produkt eller hvilken effekt de kan betragte som resultatet af delprojektet, og undervejs støtter de sig til gængse definitioner af innovation. Først kigger de på selve det materielle produkt - varmepuderne - og konstaterer, at de ikke er blevet fornyet. Så går de videre i overvejelserne og kigger efter andre mulige resultater eller effekter af delprojektet, eksempelvis plejehjemspersonalets måde at forholde sig til beboerne på. Men selv om denne ændring af arbejdsmåde muligvis ville kunne opleves som ny og som noget, der brød med det eksisterende, er problemet nu, at det ikke var det, der var intentionen med projektet, og derfor kan dette mulige udkomme nok alligevel ikke regnes som innovation, der jo ifølge nogle definitioner skal være intenderet og ikke bare tilfældig. Dernæst forsøger de at anskue det at få adgang til et nyt marked som et resultat eller et produkt af processen, selv om det heller ikke helt var det oprindelige formål med projektet og i hvert fald ikke var et formål, som alle var enige om.

Gennem samtalen prøver de på denne måde at se forskellige former for produkter eller resultater, som eventuelt kan være den kausale effekt af delprojektet, men afhængigt af hvilket resultat de vælger (produktet, arbejdsmåden eller opdagelsen af et nyt marked), når de frem til helt forskellige konklusioner på, om delprojektet så samlet set kan siges at leve op til at være innovation, og derfor var de ved samtalens slutning og i månederne efter stadig i tvivl om, hvad de skulle skrive i evalueringsrapporten om netop dette delprojekt. De var under et ret massivt politisk pres for at kunne dokumentere „noget innovation“, som kunne legitimere brugen af de mange penge og passe til styrelsens forventning om, at de skrev historien om projektet $i$ et sprog, der handlede om årsager og virkninger. Problemet var bare, at hver gang de havde fået øje på noget, der kunne anskues som den kausale effekt af en aktivitet, og som kunne „tælle som innovation“, viste det sig, at hvis man så det på en lidt anden måde, kunne konklusionen lige så godt være, at der ikke var tale om innovation, eller at det var noget andet, der udgjorde det innovative resultat og af andre grunde. 


\section{Projektbeskrivelser og evalueringer som skabelsesberetninger}

Man kunne naturligvis udsætte de forskellige fortællinger (både skriftlige og mundtlige) for en plotanalyse og komme frem til, at nogle af fortællingerne formede sig som heltefortællinger og fremstillede forandringsheltenes innovative bedrifter, mens andre formede sig som tragiske tabshistorier eller satiriske beretninger om fupnumre. Men det forholdt sig bare ikke sådan, at bestemte aktører fortalte én bestemt historie om innovationsprojektet. Tværtimod fortalte de flere forskellige historier oven i hinanden, og de talte med hinanden om, hvilke historier de skulle fortælle. Både af den grund, og fordi projektbeskrivelserne handlede om innovation og dermed om skabelse, vil jeg se på dem som skabelsesberetninger. Jeg vil nu undersøge, om den antropologiske litteratur om skabelsesberetninger kan bringe yderligere perspektiver på forholdet mellem fortællinger og forandring og innovation.

Den antropologiske litteratur på dette område er omfattende, så jeg vil følge Gisela Welz' råd og se på debatten om de historieløse folk, som ifølge Welz kan berige forståelsen af innovation (Welz 2003:257). Denne debat handlede om, hvordan europæerne har fremstillet fjerne folk som „historieløse“ og statiske, mens europæerne selv fremstod som dynamiske. Claude Lévi-Strauss gjorde allerede i 1960'erne opmærksom på, at en sådan skelnen mellem folk med og uden historie giver et uheldigt indtryk af, at nogle samfund forandrer sig, mens andre ikke gør det. Ifølge Lévi-Strauss var det imidlertid ikke tilfældet. Han mente, at det i stedet handlede om, at forskellige samfund forholdt sig forskelligt til forandring:

I så henseende er det lige så kedsommeligt som unyttigt at ophobe beviser på, at ethvert samfund er i historien, og at det forandrer sig: Det er indlysende. Men hvis man stædigt fastholder en overflødig påvisning, risikerer man ikke at forstå, at de menneskelige samfund reagerer meget forskelligt på denne fælles betingelse: Nogle accepterer den med eller mod deres vilje, og ved at blive sig den bevidst udvider de dens konsekvenser (for sig selv og for andre samfund) til et vældigt omfang; andre (som vi af denne grund vil kalde primitive) vil ikke vide af den og forsøger, med et snilde, som vi ikke forstår at værdsætte, at gøre de tilstande så permanente som muligt, som de betragter som de 'første' i deres udvikling (Lévi-Strauss 1994:235).

I stedet for at skelne mellem folk med og uden historie foreslog Lévi-Strauss i termodynamiske metaforer at skelne mellem varme og kolde samfund, hvor førstnævnte var samfund, der hilste forandringer velkomne og måske endda dyrkede dem. Den slags beskrivelser kan genfindes hos andre senere forfattere, der har understreget, at moderne vestlige samfund ikke alene hilser forandring velkommen, men ligefrem begærer det nye eller er besat af tanken om innovation 
(Campbell 1992; Welz 2003). I modsætning hertil gjorde „de kolde samfund“ ifølge Lévi-Strauss det, at de skrev forandringerne ind i deres myter og lod, som om de ikke havde fundet sted. Når nogle folk fejlagtigt var blevet beskrevet som historieløse, var det altså ifølge Lévi-Strauss ikke, fordi de var ,statiske“, men snarere fordi de forstod og forestillede sig tid, kontinuitet og forandring på andre måder, end europæerne gjorde. Således betød måden, historien blev fortalt på, at noget blev set og andet overset.

På tilsvarende vis blev de officielle historier om innovationsprojektet formuleret på en ganske bestemt måde, der betød, at arbejdet med rutiner, drift og ,plejetrummerum“, som det nogle gange omtaltes, blev andetgjort og reduceret til den statiske baggrund eller til „nulpunktet“, der muliggjorde, at det nye kunne ses, dyrkes og fremstå som noget, der havde gjort en særlig forskel. Projektbeskrivelserne og kravene om at kunne konstatere en målbar forskel mellem før og efter betød, at værdien af alt det krævende plejearbejde, der blev lagt i overhovedet at bibeholde ældre menneskers livskvalitet eller i det mindste lindre smerterne, når evner og kræfter svandt ind for til sidst at ende med døden, blev fuldstændig usynlig. På den måde blev beskrivelsen af innovationsprojektet formuleret i tråd med den forandringsbegejstring, som Lévi-Strauss ville se som udtryk for „et varmt samfund“, men tankevækkende nok bidrog den samtidig til - hvis man skal blive i de termodynamiske metaforer - at fejre ,de kolde hænders“ bedrifter på bekostning af ,de varme hænder", ${ }^{1}$ hvis betydning fremstod som usynlig og værdiløs.

Hvis man skal tage ved lære at debatten om de historieløse folk, er det værd at hæfte sig ved, hvordan en ganske bestemt måde at skrive historie på gør noget ved de andre historier. Den proces, hvorved de historieløse folk udgrænses som ,de andre“", kunne genkendes i måderne, hvorpå ,dem i driften“ og dem med „rutineopgaverne“ blev udpeget. Vedligeholdelse, pleje, lindring og alt muligt andet arbejde blev den usynlige, andetgjorte og statiske baggrund, som skulle forstyrres og innoveres, så det på baggrund af en målbar forskel mellem før og efter blev tydeligt, at en „effekt" var blevet skabt. Til gengæld forsvarede nogle af plejehjemsmedarbejderne sig mod denne andetgørelse med fortællinger om, at den slags papirprojekter kom der intet som helst ud af - de gjorde absolut ingen forskel for „virkelige“ mennesker.

I den antropologiske selvransagelse op gennem 1980'erne kom der for alvor blus på debatten om de historieløse folk og fokus på, hvordan europæere (inklusive antropologer) gennem tiden havde bidraget til misforståelsen om historieløsheden ved at fremstille andre folk, som om de ikke forandrede sig (Wolf 1982; Fabian 2002 [1983]). De moderne europæiske forestillinger om historie og tid blev koblet sammen med forestillinger om sted, således at „tilbage i tiden“ blev 
mere eller mindre ensbetydende med „langt borte“ (Hastrup 1999:31; Fabian 2002 [1983]), og på den måde forestillede europæerne sig, at eksempelvis australske aboriginere eller andre fjerne folk levede på samme måde, som de selv gjorde i for eksempel stenalderen, og at man derfor i princippet kunne rejse ud i verden og møde en tidligere version af sig selv. Men Kirsten Hastrup understreger også noget andet, som er ganske vigtigt i denne sammenhæng: at den europæiske idé om historien indbefattede, at ansvaret for historien og udviklingen blev opfattet som menneskenes og ikke som Guds eller naturens. På den måde begyndte europæerne at tænke på historien som noget, der var menneskenes værk eller bedrift (Hastrup 1999:15). De var begyndt at se sig selv som skaberne af historien og af sig selv, og de udstillede gerne bedrifterne på tidslinjer eller ved på anden måde at fremhæve, hvor langt de var nået i forhold til tidligere tider (eller i forhold til andre mennesker). Det er denne optagethed af historien som værk eller bedrift og denne fejring af forandring og fremskridt, som Lévi-Strauss forsøgte at pege på med sine begreber om „kolde“ og „varme samfund“, hvorved han forsøgte at klassificere samfund efter deres grad af forandringsbegejstring.

Peter Gow, der har forsket i myter i Amazonas, er inspireret af Lévi-Strauss, men anlægger et anderledes og mere processuelt perspektiv og forklarer, at myterne her gør arbejdet med at omformulere forandringer på måder, der opretholder kontinuiteten. Det sker ved, at forandringerne så at sige bliver „,skrevet ind i myterne", som så hele tiden forandrer sig for at indoptage det nye (Gow 2001: 11). I tråd hermed kan man finde eksempler på myter om flyvemaskiner og andre moderne opfindelser, der er blevet trukket ind i beretningerne, så det virker, som om flyvemaskiner hele tiden har været der (ibid., 288). På lignende vis beskriver Michael Jackson, hvordan aboriginerne håndterer eksistentielle spørgsmål gennem myterne, og hvordan forandringer væves ind i myterne og på den måde gøres permanente eller i hvert fald håndterbare (Jackson 1995:35-36, 55-56, 152). Hvis ikke ligefrem det nye kommer til at se ud, som om det hele tiden har været der, så kommer det i det mindste til at se ud, som om det hele tiden var meningen, at det skulle være der. Både Gow og Jackson viser således andre måder at se (eller måske snarere at overse) forandring på. Frem for at udstille, fremhæve og fejre forandringerne og de menneskelige skabere bag dem lod disse folk snarere til at usynliggøre forandringerne ved at lade dem glide ind i myterne, så forestillingen om stabilitet, kontinuitet og mening kunne opretholdes.

I det følgende vil jeg udsætte innovationsprojektets „skabelsesberetninger“ for en lignende analyse. Også her viste det sig nemlig, at beretningerne løbende blev transformeret. 


\section{Skabelsesberetninger og projektgenbrug}

Som allerede beskrevet blev det forventet af projektlederne, at de skulle levere lineære beskrivelser, der ud fra argumenter om kausalitet kunne overbevise mulige investorer om, at projektet kunne styres på en måde, der „sikrede“, at der kom innovation og værdiskabelse ud af projektet i fremtiden, og at effekten efterfølgende kunne måles.

Men de blev også mødt med andre forventninger. Disse forventninger kom hovedsagelig fra kommunens topledere og handlede om at få historien om projektet til at afspejle kommunens politikker og strategier. To gange undervejs i projektet skete det, at kommunens topledelse udstak en ny vision for fremtiden. Begge gange fik projektlederne besked om at beskrive, hvordan projektet bidrog til det, som topledelsen havde besluttet skulle være kommunens nye kurs:

Jeg fik at vide på et tidspunkt, at nu skulle jeg få vores fokusområde til at passe ind i [kommunens] fokusområde. Og så sagde jeg: 'Undskyld? Altså, det skulle jo udspringe af brugernes ønsker og ikke af [kommunens] ønsker!' Men det var lige meget [...], og så sad jeg og mingelerede - man kan jo skrive sig ud af mange ting - og fik det til at passe meget fint, og så var der ro på fronten, og så fik borgmesteren det og kunne sige: 'Neeeej, kan I se, hvor fint det her projekts fokusområde passer med vores!' Fuldstændig grotesk! For det var bare ikke det, det handlede om, og det var slet ikke den ånd, det var i. For det var innovation, og det var brugerdrevet (i Vaaben 2013:110).

Når projektlederen var så frustreret over situationen, var det både, fordi hun endte med at bruge en masse tid på at genbeskrive projektet med det resultat, at hun ikke havde tid til at gennemføre de mange aktiviteter, som projektet bestod af, og fordi hun ikke kunne se, hvad genbeskrivelsen skulle gøre godt for. Kort efter sagde hun op, og en ny blev ansat.

På et senere tidspunkt og under en ny projektleder skete noget lignende. Denne gang havde kommunen fået en ny strategi, der handlede om vækst, og selv om projektet i sin tid var blevet udtænkt som et forsøg på at lave samskabelse og innovere sig til bedre livskvalitet for ældre mennesker, var lederne nu optaget af at få genbeskrevet projektet i lyset af den nye strategi og var begyndt at interessere sig for, om de involverede virksomheder havde fået solgt noget eller viste andre tegn på vækst. For den nye projektleder betød det, at historien om projektet endnu en gang skulle skrives om, og ligesom den første projektleder oplevede hun omskrivningen som en absurd papirøvelse, der trak hendes opmærksomhed væk fra selve projektet, som hun ikke havde tid til at beskæftige sig med.

På den måde skete der løbende omskrivninger af projektet, så det kom til at passe til topledelsens aktuelle visioner. I den forstand virkede topledelsens nye strategier og fokusområder mere som noget, der udstak kursen for omskrivning af 
fortiden end som noget, der udpegede en ny kurs for det, der skulle ske i fremtiden. Forestillingerne om, at „forandringsledelse“ og ,projektledelse“ skulle handle om at udstikke en vision og omsætte den til mål og delmål, der kunne sikre målopnåelse, blev formmæssigt bekræftet og samtidig udhulet: Genbeskrivelserne tog form af historier, der levede fuldt op til sådanne forskrifter, men de virkede samtidig „bagudrettet“, forstået på den måde, at de rakte ind i fortiden og bevirkede, at historierne om et allerede igangværende projekt blev omskrevet, så lederne kunne blive overbevist om, at organisationen faktisk allerede var på vej i den nye retning. Imens gik projektet i praksis næsten i stå, idet projektlederne ikke havde tid til at beskæftige sig med det og dagligt skulle beslutte, „hvem de ville være flaskehals for i dag“", som én af dem udtrykte det.

Resultatet blev en slags projektgenbrug, hvor det samme projekt af strategiske grunde blev beskrevet igen og igen i forskellige sammenhænge for at bekræfte bestemte forestillinger om, at det, som nogen havde betalt for eller besluttet skulle ske, enten ville ske eller allerede var sket. Noget lignende sås faktisk i det indledende citat med Peter, hvor han forklarer, hvordan en politisk vision om at skabe et nyt „forskningsplejehjem“ endte med, at en række forskellige igangværende projekter og lokaler blev omdefineret og genbeskrevet, så de kunne forstås som en platform eller en grundstamme, hvorfra det blev formodet, at innovation kunne vokse frem. På den måde fik han forhandlet sig frem til en omformulering og en ommøblering af noget eksisterende, så han dels kunne leve op til de nye politiske visioner og dels kunne sikre en form for kontinuitet og fortsættelse af det, som han og andre medarbejdere ,allerede var i gang med“. De eksisterende projekter blev også her genbrugt og skrevet ind i nye sammenhænge.

Parallellen mellem de myter, der hele tiden transformeres for at skabe en fornemmelse af kontinuitet, og de løbende omskrivninger af historierne om projektet er tydelig. Dog kan man argumentere for, at de løbende omskrivninger af historien om innovationsprojektet handlede mere om at „udstille“ forandringer og nyskabelser end om at „dække over dem“ og opretholde en forestilling om kontinuitet. Historierne handlede om at fremvise innovative resultater og effekter ved at pege på et statisk „før" eller nogle statiske ,andre“.

Man kunne imidlertid også argumentere for det modsatte: at historierne på sin vis nøjagtig som myterne var med til at opretholde kontinuitet forstået på den måde, at de bekræftede og vedligeholdt det, man kunne kalde en ,moderne skabelsesberetning", der gennem lineære og kausale skildringer beskriver mennesket som skaber af historien. Derved bidrager de til at opretholde forestillingen om, at mennesker kan styre skabelsen af det nye og af fremtiden. Betydningen af tilfældigheder, magtkampe, politisk pres, økonomiske incitamenter, kompliceret lovgivning, afkobling eller svindende motivation blandt medarbejderne indgik 
ikke i disse beretninger. Alle de implicerede aktører vidste udmærket, at disse forhold spillede en rolle, og de talte løbende med hinanden om det. Ikke desto mindre var de enige om at performe projektbeskrivelserne efter de forventede forskrifter og føre dialogen om alt det andet „off the record“.

\section{Med to tunger}

De samme mennesker fortalte altså flere forskellige historier oven i hinanden eller måske uden om hinanden. Når lederen af innovationsafdelingen fortalte mig om sine strategiske overvejelser om, hvilke ord der skulle bruges, og ,hvad det gjaldt om“, viste han mig, at han kunne agere strategisk og vælge netop de ord og fortællinger, der kunne udløse bevillinger og leve op til politiske visioner, og samtidig viste han mig, at han betragtede det som en slags ,spil“. Med Gregory Batesons ord kunne man sige, at han ,metakommunikerede“ (Bateson 1972: 177ff.) og således med sin fortælling satte en særlig ramme rundt om en anden fortælling (projektbeskrivelsen) - en ramme, der gjorde ham og mig i stand til at tale om denne som en slags leg eller spil. Mange af de andre deltagere gjorde noget tilsvarende. Små fortællinger eller indskudte bemærkninger om, at ,man kan skrive sig ud af mange ting“, eller at „den slags kan jeg ikke sige på bånd“, fungerede som en metakommunikativ indramning, der udpegede en anden fortælling som en slags spil, der bare var ,som om“. Disse bemærkninger var med til at markere og indramme noget andet som værende særligt (Sjørslev 2007). På den måde blev det muligt for deltagerne i projektet at have flere forskellige fortællinger om projektet kørende samtidig.

Følger man Jakob Krause-Jensen, der har studeret HR-konsulenter i Bang \& Olufsen, hvor konsulenterne også gennem ironi og humor distancerede sig fra deres egne roller, kan der være tale om en slags strategi for at slippe ud af et „doublebind“2 (Krause-Jensen 2011:279-83). Dermed anskuer Krause-Jensen disse indramninger og fortællinger i et magtperspektiv, hvor den ironiske distance kan ses som en slags modmagt, der kaster et særligt lys af „laden som om“ over bestemte indrammede, særliggjorte eller ritualiserede aktiviteter.

Catherine Bell har haft afgørende betydning for ritualforskningen, netop fordi hun koblede studierne af ritualer sammen med Michel Foucaults begreber om magt og modmagt og introducerede begrebet „ritualisering“, som refererer til, hvordan mennesker gør bestemte praksisser særlige og mere privilegerede end andre praksisser (Bell 1992:7-8, 74 et passim). Hun forklarer, at når bestemte praksisser ritualiseres, indrammes og gøres særlige, åbner det både en mulighed for magtudøvelse og modmagtsudøvelse (op.cit.171ff.). Som eksempel nævner hun, hvordan befolkningen $i$ et totalitært land kan presses til at deltage i en ritua- 
liseret politisk begivenhed, der tillægges stor symbolsk betydning, men samtidig understreger hun også, at hver enkelt netop i kraft af ritualiseringen har mulighed for at distancere sig fra denne fysiske og kropslige deltagelse ved at opfatte den som adskilt fra en kritisk bevidsthed (op.cit.208). På sin vis kan man sige, at det var noget lignende, både Krause-Jensens HR-konsulenter og diverse ledere og projektledere i plejehjemsprojektet gjorde. De deltog i en række projektbeskrivende aktiviteter, som var ,,indrammet“, ritualiseret og ophøjet til noget særligt, i kraft af at de skulle formuleres i et bestemt sprog og efter bestemte forskrifter, der bekræftede, at det var muligt for mennesker at skabe og styre fremtidens nybrud og sikre resultaterne. Men de projektbeskrivende aktiviteter blev også indrammet og gjort særlige og anderledes end andre aktiviteter på en anden måde. Deltagerne udøvede så at sige modmagt ved at italesætte disse aktiviteter som et uvigtigt, proformapræget eller næsten latterligt spil for galleriet, en „laden som om“, som de da virkelig ikke selv troede på.

Inden for rollespil opererer man med udtrykkene ,in-game“ og „off-game“, hvor det man gør og siger ,in-game“, skal passe til den rolle, man spiller $i$ spillet, mens det, man gør og siger „off-game“, eksempelvis kan handle om selve spillet og den måde, det foregår på eller bliver ,,indrammet“ på. På samme måde kommunikerede økonomen i styrelsen både ,,in-game“ og „,off-game“, da vi talte sammen. På den ene side holdt hun sig, ,in-game“ og forklarede, hvordan det hang fint sammen at forvente, at partnerskaber og brugerinddragelse på en lineær og styrbar måde ville føre til vækst og arbejdspladser. På den anden side gav hun mig „off-game“ en hel stak papirer og en lang forklaring om, hvordan forskellige økonomiske paradigmer og lovgivninger spændte ben for hinanden.

På den ene side blev projektbeskrivelserne ritualiseret som de særlige udlægninger af projektet, der på lineære, kausale og målbare måder kunne styre projektet og sikre fremtidens innovative resultater. På den anden side gjorde ritualiseringen også deltagerne $i$ stand til at udtrykke en skepsis eller ligefrem modstand. Alle vidste, at hverken denne eller andre innovationsprocesser forløber på den enkle måde, der er beskrevet i projektbeskrivelserne eller i evalueringerne, og at en hel masse støj, rod, paradokser, doublebinds og dilemmaer er tabuiseret, usynliggjort og holdt udenfor. Men alle var også enige om at lade som om. Netop ved at ritualisere denne historieskrivning og gøre den til ,som om“ blev det muligt parallelt eller „,off-game“ at fortælle en anden historie. Og på den måde kan Krause-Jensens pointe om, at mennesker gennem en sådan distancering eller afkobling fra egne roller i arbejdslivet kan slippe ud af en form for doublebind, siges at give god mening (Krause-Jensen 2011).

Samtidig var der dog noget, der tydede på, at det at tale med to tunger og holde flere historier kørende parallelt, ikke løste problemerne med doublebinds, paradokser og moralske dilemmaer. Ganske vist bevægede rigtig mange mennesker 
i og omkring projektet sig ind og ud af en ramme og vidste fuldstændig med sig selv og hinanden, hvilke former for historier man kunne fortælle, når man var ,,ingame“, og hvilke man kunne fortælle, når man var „off-game“. Når de var inde i rammen, kunne man for eksempel ikke sætte spørgsmålstegn ved, om samarbejde og partnerskaber nødvendigvis havde en kausal forbindelse til vækst og innovation. Man kunne heller ikke spørge, om innovationsprocesser nødvendigvis var styrbare eller forløb lineært, eller om det overhovedet gav mening at betragte innovation som et „resultat“, man kunne udpege og kende årsagerne til.

„Off-game“ kunne man godt snakke om spillet eller dets indramning og om alle de tvivlsspørgsmål, dilemmaer, doublebinds og paradokser, der opstod, og som opstår i mange organisationer, der af samme grund ofte i organisationslitteraturen beskrives som ,,polyfone“ eller ,heterofone“, fordi der er mange forskellige samtidige logikker på spil (Thygesen \& Andersen 2012). Alligevel havde projektlederne, som bestemt ikke var uenige med de skeptiske stemmer blandt plejepersonalet, moralske betænkeligheder: Tænk nu, hvis de gav efter for det politiske pres og i forsøget på at udpege og fremvise „,noget innovation“ kom til at skabe et helt misvisende billede af, hvor ,innovationsfremmende“ og „værdiskabende“ de enkelte delprojekter egentlig var. Det kunne måske betyde, at fremtidige beslutningstagere i kommuner og på plejehjem landet over på baggrund af de officielle beskrivelser søsatte masser af lignende projekter i troen på, at man på den måde skabte værdi og gjorde en forskel, mens det måske reelt betød, at der blev mindre tid til plejen, som jo i samme moment blev gjort til det statiske, værdiløse nulpunkt. Den tanke var næsten ikke til at holde ud, og selv om det måske hjalp lidt at tale med to tunger, slap de ikke for at have moralske skrupler.

Søgeord: innovation, kontinuitet, forandring, fortællinger, ritualiseret praksis, offentlig sektor

\section{Noter}

1. I en dansk kontekst er udtrykkene „kolde hænder“ og „,varme hænder“ blevet flittigt brugt i debatter om, hvordan velfærdssamfundet indrettes. I den forbindelse henviser „kolde hænder“" typisk til administratorer og funktioner, der ikke direkte har assistenter, hjemmehjælpere og andre, der har direkte kontakt til patienter og borgere.

2. Begrebet „,doublebind“ stammer fra Gregory Batesons forskning og refererer til en kommunikation, der rummer to modsatrettede budskaber samtidig - for eksempel en invitation og en afvisning. Bindingen består i, at den, der oplever doublebind, ikke kan undslippe situationen uden at gøre noget forkert eller opleve et tab. 


\section{Litteratur}

Amabile, Teresa

1996 Creativity in Context. Colorado: Westview Press.

Bateson, Gregory

1972 Steps to an Ecology of Mind. Chicago \& London: University of Chicago Press.

Bell, Catherine

1992 Ritual Theory, Ritual Practice. New York: Oxford University Press.

Boje, David M.

2006 Breaking out of Narrative's Prison: Improper Story in Storytelling Organization. Story, Self, Society: An Interdisciplinary Journal of Storytelling Studies 2(2):2849.

Fabian, Johannes

2002 [1983] Time and the Other: How Anthropology Makes Its Object. New York: Columbia University Press.

Gow, Peter

2001 An Amazonian Myth and Its History. London \& New York: Oxford University Press.

Hastrup, Kirsten

1999 Viljen til viden: En humanistisk grundbog. København: Gyldendal.

Humle, Didde Marie

2014 The Ambiguity of Work: Work Practice Stories of Meaningful and Demanding Consultancy Work. Nordic Journal of Working Life Studies 4(1):119-37.

Jackson, Michael

1995 At Home in the Wold. Durham \& London: Duke University Press.

1998 Minima Ethnographica: Intersubjectivity and the Anthropological Project. Chicago: University of Chicago Press.

2002 The Politics of Storytelling: Violence, Transgression and Intersubjectivity. Copenhagen: Museum Tusculanum Press.

Krause-Jensen, Jakob

2011 Ideology at Work: Ambiguity and Irony of Value-Based Management in Bang \& Olufsen. Ethnography 12(2):266-89.

Lévi-Strauss, Claude

1994 Den vilde tanke. København: Gyldendal.

Lex, Simon

2016

In Search of Innovation: Operating with the Future as Working Imperative. Human Organization 65(3):230-38.

Ochs, Elinor \& Lisa Capps

2001 Living Narrative. Cambridge \& London: Harvard University Press.

Osborne, Stephen P. \& Kerry Brown

2005 Managing Change and Innovation in Public Service Organisations. London \& New York: Routledge. 
Pedersen, Anne Reff

2014 Narrativ organisationsteori. I: S. Vikkelsø \& P. Kjær (red.): Klassisk og moderne organisationsteori. Side 301-16. København: Hans Reitzels Forlag.

Pedersen, Anne Reff \& Mette Brehm Johansen

2011 En organisationsteoretisk rejse gennem innovationslandskabet. I: E. Sørensen \& J. Torfing (red.): Samarbejdsdrevet innovation i den offentlige sektor. Side 101-15. København: Jurist- og Økonomforbundets Forlag.

Sørensen, Eva \& Jacob Torfing

2011 Samarbejdsdrevet innovation - i den offentlige sektor. I: E. Sørensen \& J.

Torfing (red.): Samarbejdsdrevet innovation i den offentlige sektor. Side 19-40.

København: Jurist- og Økonomforbundets Forlag.

Thygesen, Niels \& Niels Åkerstrøm Andersen

2012 The Polyphonic Effects of Technological Changes in Public Sector Organizations:

A Systems Theoretical Approach. In: N. Thygesen (ed.): The Illusion of

Management Control. Pp. 159-83. New York: Palgrave Macmillan.

Ven, Andrew H. Van de, Douglas E. Polley, Raghu Garud \& Sankaran Venkataraman

2008 The Innovation Journey. Oxford \& New York: Oxford University Press.

Vaaben, Nana

2013 Innovations-, samarbejds- og styringsfantasmer i det offentlige. Roskilde: Roskilde Universitet.

Welz, Gisela

2003 The Cultural Swirl: Anthropological Perspectives on Innovation. Global Networks 3(3):255-70.

Wolf, Eric

1982

Europe and the People without History. Berkeley: University of California Press. 
